\title{
Epidemiology of gonococcal vulvovaginitis among children in the tropics*
}

\author{
K O ALAUSA AND A O OSOBA \\ From the Special Treatment Clinic, Department of Medical Microbiology, University College Hospital, \\ Ibadan, Nigeria
}

SUMMARY In a three-year prospective clinical study, 42 children aged between 1 and 12 years were found to have gonococcal vulvovaginitis. Epidemiological investigations showed that contaminated fomites-particularly bedclothing, underclothing, and towels-and precocious sexual intercourse were the important vehicles of transmission of gonococci to the genital tract of these children.

\section{Introduction}

Vulvovaginitis in childhood can be of gonococcal or nongonococcal origin; the latter condition can be caused either by infectious agents, such as Candida albicans, Trichomonas vaginalis, diphtheroid bacilli, haemophilus species, streptococcal species, staphylococcal species, Escherichia coli, and thread worms, or by non-infectious substances, such as foreign bodies in the vagina and malnutrition in the presence of poor personal hygiene. Gonococcal vulvovaginitis is the most serious of the two conditions and it has been recognised as an important disease in tropical and developing African countries. For example, Lawson and Stewart ${ }^{1}$ stated that four out of five cases of vulvovaginitis in the tropics were due to infection with Neisseria gonorrhoeae, and Osoba and Alausa ${ }^{2}$ found gonococci in 16 of the 17 children with vulvovaginitis in Ibadan. However, vulvovaginitis caused by $\mathbf{N}$ gonorrhoeae is considered rare in developed temperate countries of the world. ${ }^{3}$

This report summarises our experience of the clinical features and important epidemiological determinants in $\mathbf{4 2}$ consecutive cases of gonococcal vulvovaginitis in children seen at the Special Treatment Clinic (STC), University College Hospital, Ibadan, Nigeria, over a three-year period from July 1976 to June 1979.

\footnotetext{
*Presented at the First African Conference on Sexually Transmitted Diseases, Ibadan, Nigeria, 22-24 August 1979

Address for reprints: Dr K O Alausa, Special Treatment Clinic, Department of Medical Microbiology, University College Hospital, Ibadan, Nigeria

Received for publication 23 October 1979
}

\section{Patients and methods}

\section{STUDY POPULATION}

Thirty-eight consecutive prepubertal girls with confirmed gonococcal vulvovaginitis aged between 1 and 12 years, who were referred by other physicians or brought into the STC by their parents or guardian, were included in the study. These children were grouped as the index cases to distinguish them from the four contact cases who were found to have gonococcal vulvovaginitis after being asked by contact-tracers to attend the clinic. Three of the contact cases were sisters of index cases while the fourth was a housemaid in the family of one of the index cases.

\section{CLINICAL INVESTIGATIONS}

A detailed history of the onset of symptoms was taken from the patients' escorts. Inquiries about the possibilities of sexual assault, where and with whom the child slept, the bath towel she used, and the type of toilet facilities in the home and school were also made.

The children were physically examined and their nutritional state and standard of personal hygiene were noted. The underwear was closely inspected for blood stains or vaginal discharge. The vulva was examined for the presence of discharge, ulcers, bleeding sites, and evidence of sexual assault; the condition of the hymen was also noted. The vulva was then cleaned with a sterile cottonwool swab and visualised with a nasal speculum for foreign bodies.

\section{LABORATORY INVESTIGATIONS}

Two vaginal swabs and one urethral swab were taken and sent immediately to the laboratory for demonstration and identification of the gonococcus, 
according to the method previously described by Osoba and Alausa. ${ }^{2}$ A wet preparation in saline of one of the vaginal swabs was made and examined for yeasts, trichomonads, worms, and ova. Urine specimens were collected for microscopical examination and culture. A specimen of blood was also taken for the Venereal Disease Research Laboratory test.

\section{CONTACT-TRACING}

The members of the family of each child were asked to attend the clinic for examination, investigation, and treatment if necessary. The health sister in charge of the clinic was responsible for ensuring that members of the family of infected children attended the clinic. On a few occasions she had to visit the homes of the child's parents before they agreed to attend the clinic. The health sister also gave health education talks to parents, particularly on the modes of transmission and control of childhood gonorrhoea.

\section{Results}

\section{CLINIC ATTENDANCES}

During the three-year period, a total of 2900 new patients were seen at the STC; these consisted of 1773 male and 1127 female patients. The number of patients who harboured gonococci was 366-251 male patients $(14.2 \%$ of the 1173 male cases) and 115 female patients $(10 \cdot 2 \%$ of the 1127 female cases). Forty-two $(36.5 \%)$ of the 115 female patients harbouring gonococci were children aged between 1 and 12 years - that is, $11.5 \%$ of all cases harbouring gonococci seen at the STC over the three-year period.

\section{AGE DISTRIBUTION}

Of the 42 children, $30(71 \cdot 4 \%)$ were between 1 and 6 years (table I); 25 of these were under school age. All the five children (three index cases and two contact cases) over 10 years had had previous sexual exposure and had a torn hymen on examination.

\section{CLINICAL FEATURES}

Vaginal discharge was the single most common symptom that prompted the parents or guardians of 38 of the children to seek medical advice (table II).

TABLE I Age distribution of 42 children with vulvovaginitis

\begin{tabular}{llll}
\hline & \multicolumn{2}{l}{ No of patients } & \\
\cline { 2 - 3 } Age group (years) & Index cases & Contact cases & Total \\
\hline$<1$ & 0 & 0 & 0 \\
$1-3$ & 13 & 1 & 14 \\
$4-6$ & 16 & 0 & 16 \\
$7-9$ & 6 & 1 & 7 \\
$10-12$ & 3 & 2 & 5 \\
Total & 38 & 4 & 42 \\
\hline
\end{tabular}

TABLE II Clinical features in 42 children with gonorrhoea

\begin{tabular}{llc}
\hline Clinical features & $\begin{array}{l}\text { No of } \\
\text { cases }\end{array}$ & $\begin{array}{l}\text { \% of } \\
\text { total cases }\end{array}$ \\
\hline Vaginal discharge & 38 & $90 \cdot 5$ \\
Pruritus vulvae & 10 & $23 \cdot 8$ \\
Dysuria & 4 & $9 \cdot 5$ \\
Fever & 3 & $7 \cdot 1$ \\
Frequency of micturition or enuresis or both & 2 & $4 \cdot 8$ \\
Lower abdominal pain & 2 & $4 \cdot 8$ \\
Vulval ulceration and bleeding & 1 & $2 \cdot 4$ \\
Torn hymen (found on examination) & 5 & $11 \cdot 9$ \\
\hline
\end{tabular}

The duration of the vaginal discharge ranged between two days and three months depending on whether the child was staying with the mother, stepmother, or other relations; usually the mother of the child would seek medical help earlier than would other guardians. In addition, the parents' previous experiences affected their reaction to the child's symptoms before seeking medical advice; generally, a mother with previous experience or knowledge of the disease would bring her child to hospital early. The only child seen during examination with vulval ulceration and bleeding was staying with her father, who was applying an antiseptic solution to cleanse the child's vaginal discharge; he decided to seek medical help after two weeks when there was no improvement in the child's condition.

\section{FAMILY CONTACTS}

In each of the two families where three cases of prepubertal gonorrhoea were found per family (table III), there was an older child of between 10 and 15 years with previous experience of sexual intercourse and gonorrhoea; one of these older girls was a housemaid aged 15 years (who was not included in the study).

\section{SOURCE OF INFECTION}

The results of family investigations to determine the probable source of infection among the 38 index cases are shown in tables IV and V. Only 22 mothers and $\mathbf{1 7}$ fathers of the $\mathbf{3 4}$ families involved responded to our request to attend the clinic.

The role played by older women in the transmission of gonorrhoea within the family is well illustrated. Mothers, sisters, and housemaids

TABLE III Family cluster of children with prepubertal gonorrhoea

\begin{tabular}{lcc}
\hline Cases per family & \multicolumn{2}{c}{ No of families } \\
\hline 1 & 28 & $(82 \cdot 4 \%)$ \\
2 & 4 & $(11 \cdot 7 \%)$ \\
3 & 2 & $(5 \cdot 9 \%)$ \\
Total $(\%)$ & 34 & $(100 \%)$ \\
\hline
\end{tabular}


TABLE IV Sources of infection among the 38 index cases

\begin{tabular}{|c|c|c|c|c|}
\hline \multirow{2}{*}{$\begin{array}{l}\text { Relationship } \\
\text { to index case }\end{array}$} & \multirow{2}{*}{$\begin{array}{l}\text { No } \\
\text { examined }\end{array}$} & \multicolumn{3}{|c|}{ No harbouring } \\
\hline & & Gonococci & Trichomonads & Yeasts \\
\hline Mother* & 22 & 8 & 4 & 5 \\
\hline Father* & 17 & 4 & 0 & 0 \\
\hline Sister & 23 & $3+$ & 1 & 0 \\
\hline Brother & 10 & 0 & 0 & 0 \\
\hline Housemaid & 3 & $2+$ & 1 & 1 \\
\hline Houseboy & 2 & 0 & 0 & 0 \\
\hline \multirow{2}{*}{$\begin{array}{l}\text { Other relatives } \\
\text { (stepmother, } \\
\text { cousins, } \\
\text { aunts) }\end{array}$} & & & & \\
\hline & 6 & 1 & 0 & 1 \\
\hline Total & 83 & 18 & 6 & 7 \\
\hline
\end{tabular}

*Two couples (mother and father) harboured gonococci

†Three sisters and one housemaid were contact cases

accounted for 13 of the 18 family contacts with gonorrhoea out of the 83 investigated (table V). Although none of the 42 children included in the study had trichomoniasis or candidosis, some of the female members of the families of index cases had these conditions. Four sisters of one index case had scabies but none had gonorrhoea; no other cases of scabies were found.

\section{Discussion}

The high rate of positive gonococcal isolation among girls under 12 years attending the STC in Ibadan indicates the importance of gonococcal vulvovaginitis as a public health hazard in Nigeria and other parts of developing tropical Africa. The fact that $36.5 \%$ of gonococcal isolates from female patients during the three-year period were from children under 12 years does not however imply that over one-third of female cases of gonorrhoea seen in our hospital are under 12 years. This is because other departments in the hospital continue to see older women with gonorrhoea. Because of the unique position of the STC as the main diagnostic and treatment centre specifically devoted to the management of sexually transmitted diseases in Ibadan, most of the children with vaginal discharge are referred to the STC by physicians all over the city for proper diagnosis and treatment. We are therefore dealing with a highly selective population of children with this infection.

Several factors have been suggested for the apparent high prevalence of childhood gonococcal infection in the tropical developing countries of Africa. Firstly, the ability of the gonococcus to survive longer outside the body in the presence of the high relative humidity (up to $90 \%$ during the rainy season) of the tropics, and thus allowing clothes and other fomites contaminated with gonococci to remain infective for at least 3-4 hours, has been demonstrated experimentally by Alausa and others ${ }^{4}$ and epidemiologically by Osoba and Alausa ${ }^{2}$ in Ibadan. In Nigeria, as in other developing countries, most urban family units consisting of the husband, one or more wives, several children, and other relatives live in crowded one-room or two-room rented shared dwellings in slum areas, and the practice of children and adults sharing the same bedclothing and towels is still very common.

Secondly, in Nigeria, where effective treatment for gonorrhoea is not generally and easily available, the disease is endemic; it is listed as the fifth cause of morbidity when all major notifiable diseases are considered (coming only after malaria, dysentery, measles, and pneumonia).

Thirdly, the socio-economic system in most developing countries still permits child labour, so that older children who cannot be maintained financially by their parents are sometimes hired out as housemaids or houseboys to families in the middle and upper economic strata of the community. These "servants" are usually left at home in charge of children while the parents are at work or attending social functions.

Lastly, polygamy is an acceptable way of living among many of the less educated and poorer people

TABLE V Probable sources of infection in 42 children with prepubertal gonorrhoea

\begin{tabular}{|c|c|c|}
\hline Mode/source of infection & No of cases & Clinical and epidemiological findings \\
\hline $\begin{array}{l}\text { Infected parents (mother or } \\
\text { father or both) and relatives } \\
\text { (stepmother, cousin, aunt) }\end{array}$ & 12 & $\begin{array}{l}\text { Sleeping on same bed or mat with parents/relatives and sharing the same } \\
\text { bedcover/towel with them. (Parents/relatives were found to have } \\
\text { gonorrhoea during family investigation.) }\end{array}$ \\
\hline $\begin{array}{l}\text { Previous sexual exposure or } \\
\text { assault (promiscuity) }\end{array}$ & $5^{*}$ & $\begin{array}{l}\text { Torn hymen discovered at examination. (Evidence of previous sexual } \\
\text { intercourse with infected person.) }\end{array}$ \\
\hline Infected sisters & 4 & $\begin{array}{l}\text { (Four contact cases.) Elder sisters had gonorrhoea about the same time. } \\
\text { Sibs shared underwear with elder sisters. }\end{array}$ \\
\hline Infected housemaids & 4 & $\begin{array}{l}\text { A } 15 \text {-year-old housemaid with gonorrhoea and trichomoniasis was } \\
\text { sleeping in same bed with three of the children (aged } 2,4 \text {, and } 6 \text { years) } \\
\text { with gonorrhoea. Another housemaid with gonorrhoea was sleeping in the } \\
\text { same bed with another child in the study. }\end{array}$ \\
\hline Undetermined source of infection & 17 & - \\
\hline
\end{tabular}

${ }^{*}$ All five cases were aged between 10 and 12 years. 
(Yorubas) living in Ibadan. Casual sexual relationships are also common; hence, the risk of disseminating sexually transmitted diseases in the community is very high.

Because of the importance of contaminated fomites-particularly bedclothing, underwear, and towels-and precocious sexual intercourse in transmitting gonococci to the genital tract of Nigerian children, adults who present for treatment of acute gonorrhoea should be warned that they may not only spread infection by sexual contact but may also be a source of danger to young children who may not even come into immediate contact with them.

\section{References}

1. Lawson JB, Stewart DB. Obstetrics and Gynaecology in the Tropics, 1st ed. London; Edward Arnold Ltd, 1967:411.

2. Osoba AO, Alausa KO. Vulvovaginitis in Nigerian children. Niger J Paediatr 1974; 1:26-32.

3. Jeffcoate TNA. Principles of Gynaecology, 3rd ed. London: Butterworth Press, 1967:394.

4. Alausa KO, Sogbetun AO, Montefiore D. Effert of drying on Neisseria gonorrhoeae in relation to non-venereal infection in children. Niger J Paediatr 1977; 4(1): 14-8. 